\title{
Preliminary Study of Corrosion Status on Bronzes Excavated from Qin Dynasty Tombs at Xinfeng Town in China
}

\author{
Qian-li Fu, ${ }^{1}$ Pu-jun Jin, ${ }^{2}$ Xue Ling, ${ }^{3}$ Shang-xin Zhang, ${ }^{1}$ Wei-gang Sun, ${ }^{4}$ and Yin Xia ${ }^{1}$ \\ ${ }^{1}$ Emperor Qin's Terra-Cotta Warriors \& Horses Museum, Lin Tong, Shaanxi Province, Xi'an 710600, China \\ ${ }^{2}$ School of Materials Science and Engineering, Shaanxi Normal University, Chang An South Road 199\#, \\ Shaanxi Province, Xi'an 710062, China \\ ${ }^{3}$ School of Cultural Heritage, Northwest University, Tai Bai North Road 229\#, Shaanxi Province, Xi'an 710069, China \\ ${ }^{4}$ Institute of Archaeology of Shaanxi, Yan Ta Region, Shaanxi Province, Xi'an 710043, China
}

Correspondence should be addressed to Pu-jun Jin, jinpj@snnu.edu.cn

Received 10 August 2011; Revised 22 January 2012; Accepted 24 January 2012

Academic Editor: Rokuro Nishimura

Copyright (C) 2012 Qian-li Fu et al. This is an open access article distributed under the Creative Commons Attribution License, which permits unrestricted use, distribution, and reproduction in any medium, provided the original work is properly cited.

From 2007 to 2008, many bronze wares of Qin Dynasty were excavated from tombs at Xinfeng town. Being an important finding, these bronze wares attracted people's attention, especially for their conservation. Therefore, the corrosive products were explored by using Scanning Electron Microscope with Energy Dispersive X-ray Detector (SEM/EDS), X-Ray diffraction (XRD), and Raman spectroscopy $(\mathrm{RM})$, which provided much valuable information on the conservation of these bronze wares. According to tested results, the corrosive products of bronzes were found to be comprised of cuprite $\left(\mathrm{Cu}_{2} \mathrm{O}\right)$, covellite $(\mathrm{CuS})$, lead carbonate $\left(\mathrm{PbCO}_{3}\right)$, and malachite $\left(\mathrm{CuCO}_{3} \cdot \mathrm{Cu}(\mathrm{OH})_{2}\right)$. Meantime, the multilayer corrosive structure was found in some samples due to the cracks in $\mathrm{Cu}_{2} \mathrm{O}$ layer which had formed many microchannels to promote the material migration.

\section{Introduction}

From 2007 to 2008, about six hundred Qin Dynasty tombs were unearthed by archaeologists at Xinfeng town in Xi'an city, Shanxi province, China. It was reported as a significant archaeological excavation to dig out the largest number and scale of the Qin tombs in the central Shaanxi plain [1].

The site located south shore secondary tableland of Wei He River which was a domicile named as "Xiyi" where ceramics craftman had once lived to build Qin Shi Huang Mausoleum [2].

A lot of bronzes were unearthed from these tombs, such as bronze ding tripod, bronze dou, bronze hu, and arrow, many of which were broken and in severe corrosion [2].The bronzes are ternary alloy with the element of $\mathrm{Cu}, \mathrm{Sn}$, and $\mathrm{Pb}$ that would be in different corrosive situation after a long buried time [3]. In general, people had always research the corrosive mechanism of ancient bronze by analyzing on corrosive products or doing the simulated experiments $[4,5]$. The analysis of corrosive products will supply important information to protect them and also provide important reference to research their corrosive mechanism. This paper studied the corrosive products from the bronze fragments by Scanning electron microscope with energy dispersive X-ray detector (SEM/EDAX), X-Ray diffraction (XRD), and Raman spectroscopy (RM) and revealed the corrosive situation and mechanism on them.

\section{Samples and Methods}

2.1. Test Samples. In this paper, eight samples form different bronzes were studied, as shown in Table 1. All of them were collected from bronze fragile pieces, whose section was dealt with coarse grinding and polishing before the experiment.

2.2. Instrumentation. The cross-section morphologies were examined by a digital optical microscope (Keyence, VHX$600 \mathrm{~K}$, Japan), which has large depth of field and was equipped with a 3 CCD camera about 54 million pixels. Xray diffraction (XRD) was obtained in a Rigaku D/Max3C X-ray diffractometer, equipped with a $\mathrm{Cu} \mathrm{K} \alpha$ radiation 
TABLE 1: The record of test samples collected from bronze fragile piece at Xinfeng town.

\begin{tabular}{lcccc}
\hline Number & Tombs/Implements & Sample site & Time & Location \\
\hline Sample 1 & M274/bronze $h u$ & Abdomen & Qin & Xinfeng town \\
Sample 2 & M83/bronze ding & Bottom & Qin & Xinfeng town \\
Sample 3 & M691/bronze ding & Bottom & Qin & Xinfeng town \\
Sample 4 & M301/bronze ding & Bottom & Qin & Xinfeng town \\
Sample 5 & M55/bronze ding & Bottom & Qin & Xinfeng town \\
Sample 6 & M268/bronze $h u$ & Abdomen & Qin & Xinfeng town \\
Sample 7 & M04/bronze $h u$ & Abdomen & Qin & Xinfeng town \\
Sample 8 & M256/bronze pen & Edge & &
\end{tabular}

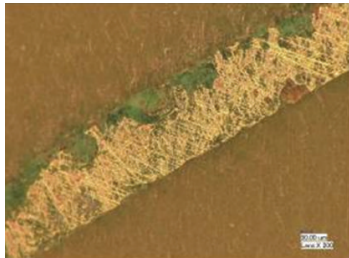

Section of sample 1

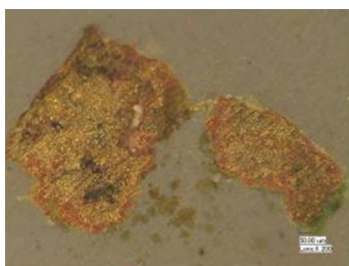

Section of sample 5

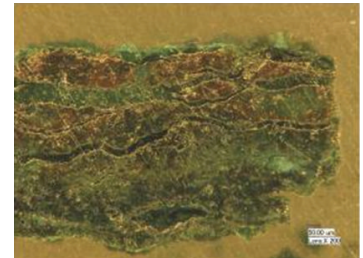

Section of sample 2

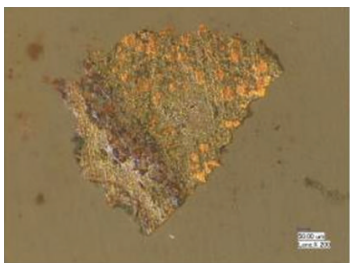

Section of sample 6

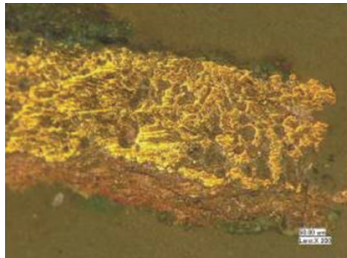

Section of sample 3

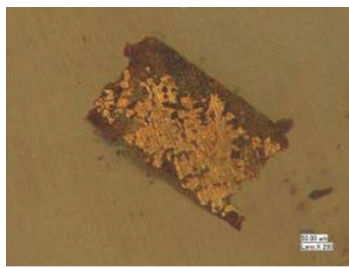

Section of sample 7

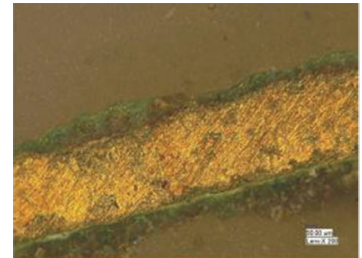

Section of sample 4

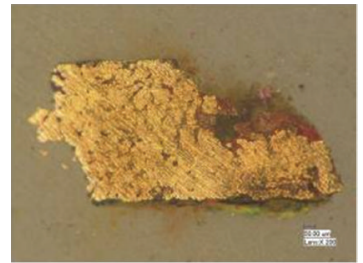

Section of sample 8

Figure 1: Section photomicrograph of bronze samples.

source $(\lambda=0.154056 \mathrm{~nm})$ in the $2 \theta$ range from $10^{\circ}$ to $70^{\circ}$, tube voltage $40 \mathrm{KV}$, current $40 \mathrm{~mA}$. A FEI-Quanta 200 environment scanning electron microscopy (SEM) equipped with an X-ray energy dispersive spectroscopy (EDS) was used to research samples, which were examined in the highvacuum mode and low high-vacuum mode at an accelerating voltage about $20 \mathrm{kV}$. Roman spectra were attained by a microscopic confocal Raman Spectrometer(Renishaw in via Plus, England) employing a $514 \mathrm{~nm}$ laser beam excited by argon ion laser with information collection time about $10 \mathrm{~s}$ and accumulation time about $3 \sim 5 \mathrm{~s}$.

\section{Results}

3.1. Optical Microscope Analysis. The cross section of samples indicated that these bronze fragile pieces were a serious corrosion, as shown in Figure 1. Many samples had similarly corrosive situation, such as sample $1,3,4,5,6,7$, and 8 , which had outer green rust layer and inner red rust layer [6]. Specially, the section of sample 2 demonstrated a multilayer dust, which had the existence of alternate red and green corrosive product layer.

3.2. Backscattered Electron Phase and Component Analysis. After samples were inlaid into Acrylic resin, they were dealt with surface grinding and polishing. Then sample 1, 2, 3, and
6 were analyzed by SEM/EDS, whose electron images were attained by backscattered electron and elementary content were detected by X-ray energy dispersive spectroscopy (EDS), data as shown in Table 2.

There are four scanning area of sample1, such as Area1 to Area-4, as shown in Figure 2. The result indicates that Area-1 and Area-2 were outer layer of corrosion with complex component, especially with high content of $\mathrm{C}$ and $\mathrm{O}$ element, which revealed that the surface layer of sample had been corroded. Meantime, the backscattered electron images of Area-3 take on a white look which due to $\mathrm{PbCO}_{3}$ according to the high content of some element as $20.53 \% \mathrm{C}$ $12.4 \% \mathrm{O}$ and $67.07 \% \mathrm{~Pb}$. The analyzed Area- 4 revealed that a significant amount of $83.63 \% \mathrm{Cu}$ and $16.37 \% \mathrm{Sn}$, which should be remnant $\alpha$-phase in bronze alloy.

For sample 2, four areas were analyzed about Area-5 to Area-8, as shown in Figure 2. The analyzed Area-5 is middle area of red corrosive product layer whose component is complex with $36.46 \%$ C, $43.55 \%$ O, $14.13 \% \mathrm{Cu}, 5.29 \% \mathrm{~Pb}$ and $0.57 \% \mathrm{Si}$, which mean that the red corrosive product layer $(\mathrm{Cu} 2 \mathrm{O})$ contains impurities. The complex composition of $27.48 \% \mathrm{C}, 26.67 \% \mathrm{O}, 3.74 \% \mathrm{Cu}$, and $42.11 \% \mathrm{~Pb}$ indicates that lead carbonate is main corrosive product in the other analyzed Area-6.

Five areas of sample3 were analyzed, Area-7 is $\alpha$-phase in bronze alloy with $86.61 \% \mathrm{Cu}$ and $13.39 \% \mathrm{Sn}$; Area- 8 is 
TABLE 2: The content of composite element of samples (wt\%).

\begin{tabular}{|c|c|c|c|c|c|c|c|c|c|c|c|c|c|c|c|c|c|}
\hline & & & & & & & Element & & & & & & & & & & \\
\hline Area & $\mathrm{C}$ & $\mathrm{O}$ & $\mathrm{Cu}$ & Sn & $\mathrm{Pb}$ & $\mathrm{Ca}$ & $\mathrm{Si}$ & $\mathrm{Al}$ & $S$ & As & $\mathrm{K}$ & $\mathrm{Fe}$ & $\mathrm{Mg}$ & $\mathrm{Ni}$ & $\mathrm{Cl}$ & $\mathrm{Na}$ & $\overline{\mathrm{P}}$ \\
\hline Area-1 & 18 & 52.79 & 26.08 & & 2.67 & 0.46 & & & & & & & & & & & \\
\hline Area-2 & 19.17 & 31.19 & 18.46 & 22.35 & 7.15 & & 1.25 & 0.42 & & & & & & & & & \\
\hline Area-3 & 20.53 & 12.4 & & & 67.07 & & & & & & & & & & & & \\
\hline Area-4 & & & 83.63 & 16.37 & & & & & & & & & & & & & \\
\hline Area-5 & 36.46 & 43.55 & 14.13 & & 5.29 & & 0.57 & & & & & & & & & & \\
\hline Area-6 & 27.48 & 26.67 & 3.74 & & 42.11 & & & & & & & & & & & & \\
\hline Area-7 & & & 86.61 & 13.39 & & & & & & & & & & & & & \\
\hline Area-8 & 8.69 & 5.86 & 54.28 & 31.17 & & & & & & & & & & & & & \\
\hline Area-9 & & 20.07 & 79.93 & & & & & & & & & & & & & & \\
\hline Area-10 & 16.61 & 6.08 & 57.82 & & & & & & 19.5 & & & & & & & & \\
\hline Area-11 & 11.34 & 22.08 & 27.26 & 16.55 & 16.66 & & & & & 2.42 & & & & & 3.69 & & \\
\hline Area-12 & 26.07 & 4.77 & 69.16 & & & & & & & & & & & & & & \\
\hline Area-13 & 15.82 & 45.55 & & & 2.04 & & 21.79 & 7.94 & & & 5.89 & & & & & 0.97 & \\
\hline Area-14 & 23.24 & 34.74 & 5.99 & & 24.49 & 1.47 & 4.43 & 2.11 & & & & 1.57 & 0.63 & 1.34 & & & \\
\hline
\end{tabular}
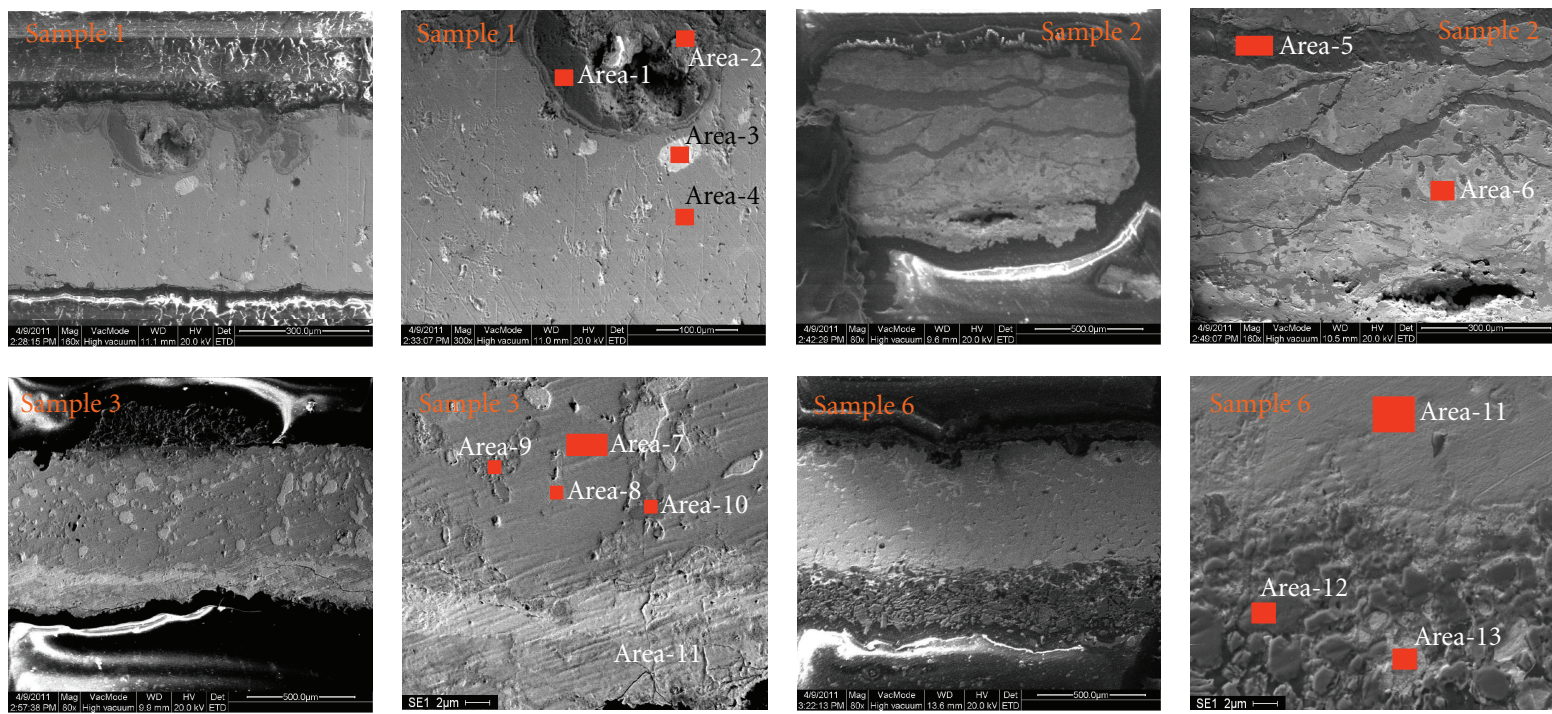

FIGURE 2: SEM photograph of sample cross section and drawing of site of energy spectrum analysis area.

the remnant $\alpha$ - $\delta$ phase with $8.69 \%$ C, $5.86 \%$ O, $54.28 \% \mathrm{Cu}$, and $31.17 \% \mathrm{Sn}$; Area-9 is dull color area where is composed of $20.07 \% \mathrm{O}$ and $79.93 \% \mathrm{Cu}$, which suggest the existence of copper oxide [7]; Area-10 is dark area with 19.5\% S in which there are some copper sulfide; Area-11 shows white with complex composition and $16.66 \% \mathrm{~Pb}$.

Sample 6 was analyzed in three areas from Area-12 to Area-14, as seen in Figure 2. In the Area-14, the high content of $24.49 \% \mathrm{~Pb}$ element was detected by EDS which is more than that in Area-13. In fact, Area-13 has complex component of $15.82 \% \mathrm{C}, 45.55 \% \mathrm{O}, 2.04 \% \mathrm{~Pb}, 21.79 \% \mathrm{Si}$, $7.94 \% \mathrm{Al}, 5.89 \% \mathrm{~K}$, and $0.97 \% \mathrm{Na}$ which means this area is soil. On the other hand, $\mathrm{Pb}$ element wasn't found in the analyzed Area-12. It could draw a conclusion that element $\mathrm{Pb}$ has the trend of migration from the bronze alloy to the circumambient soil.
3.3. Secondary Electron Image of Sample 2. The secondary electron image of sample 2 showed obviously multilayer structure about corrosive layer, as seen in Figure 3. The zonal cuprite could be seen in the SEM image in which many cracks also were observed clearly.

3.4. Analysis of XRD. The XRD pattern of sample (Figure 4) showed that the peaks at $29.6^{\circ}, 36.5^{\circ}, 42.4^{\circ}$, and $61.5^{\circ}$ can be indexed to $\mathrm{Cu}_{2} \mathrm{O}$ (JCPDS Card No. 77-0199). Other diffraction peaks at $23.4^{\circ}, 25.5^{\circ}, 29.7^{\circ}, 34.5^{\circ}, 36.7^{\circ}, 43.3^{\circ}$, and $49.7^{\circ}$ can be indexed to $\mathrm{PbCO}_{3}$ (JCPDS Card No. 030358).

3.5. Raman Spectrum. Different color corrosive product of cross section of sample 2 and sample 6 was analyzed by Micro-Raman spectroscopy. Figures 5(a) and 6(a) show 


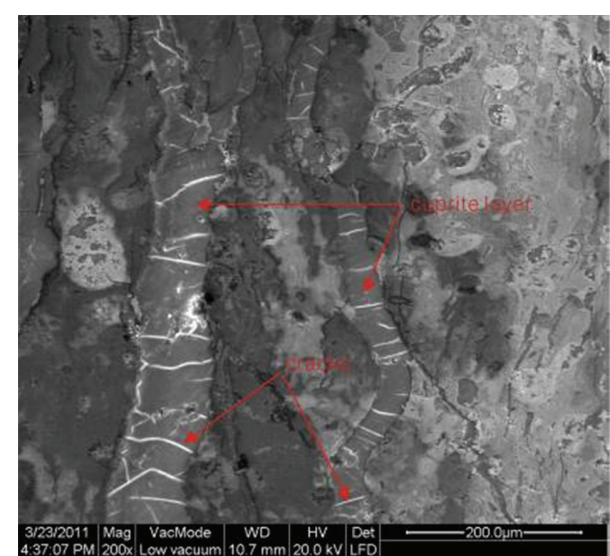

FIGURE 3: Morphology photograph of cross section of sample no. 2.

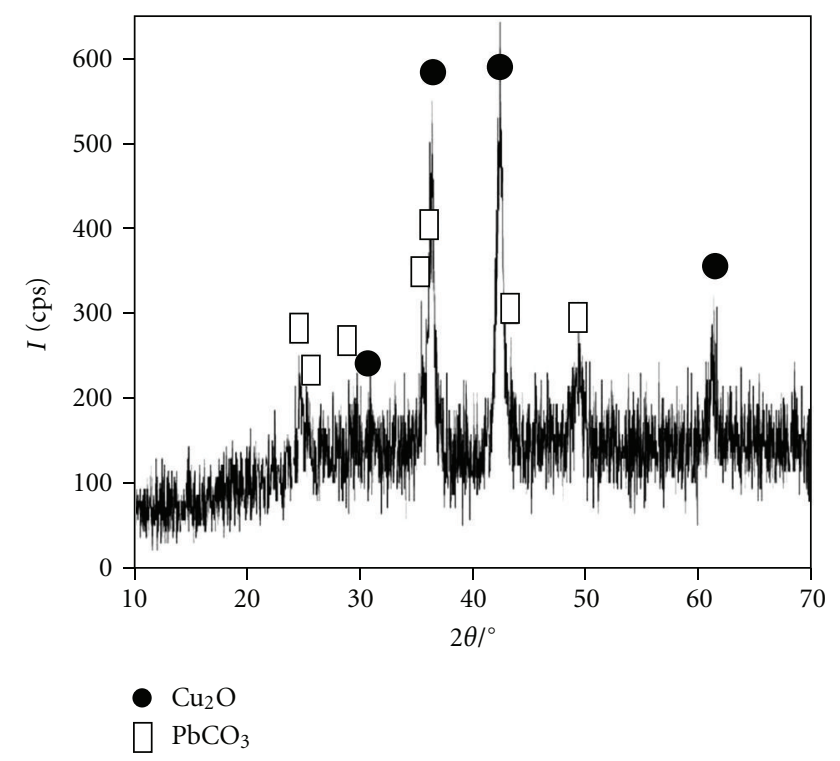

FIgURE 4: X-ray diffraction pattern of sample 1.

Raman pattern of patina from two sampels which displayed vibration peaks at $1493 \mathrm{~cm}^{-1}$ (vs), $1051 \mathrm{~cm}^{-1}$ (vs), $431 \mathrm{~cm}^{-1}$ (vs), $266 \mathrm{~cm}^{-1}(\mathrm{~m})$, and $177 \mathrm{~cm}^{-1}$ (s) due to malachite $\left(\mathrm{CuCO}_{3} \cdot \mathrm{Cu}(\mathrm{OH})_{2}\right.$ [8]. The red corrosive product demonstrates Raman vibration peaks at $636 \mathrm{~cm}^{-1}(\mathrm{~s}), 413 \mathrm{~cm}^{-1}$ (m), $213 \mathrm{~cm}^{-1}$ (vs), and $146 \mathrm{~cm}^{-1}$ (m) corresponding to cuprous oxide $\left(\mathrm{Cu}_{2} \mathrm{O}\right)$ [9], as shown in Figures 5(b) and 6(b). Figure 5(c) shows Raman pattern of blue corrosive product from sample 2 with a vibration peak at $472 \mathrm{~cm}^{-1}$ (vs) due to copper sulphide (CuS) $[10,11]$.

\section{Discussion}

The analytical result of XRD indicates that two kinds of corrosive products existed in most collected test samples, which are $\mathrm{Cu}_{2} \mathrm{O}$ and $\mathrm{PbCO}_{3}$. Actually, the signal of patina was not detected by XRD, which was confirmed by Raman spectroscopy as malachite $\left(\mathrm{CuCO}_{3} \cdot \mathrm{Cu}(\mathrm{OH})_{2}\right)$.

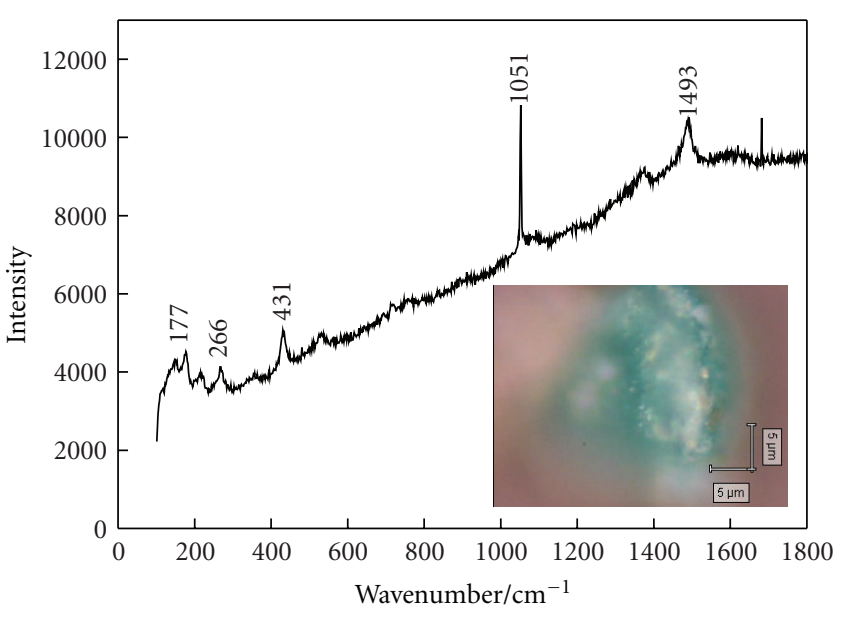

(a)

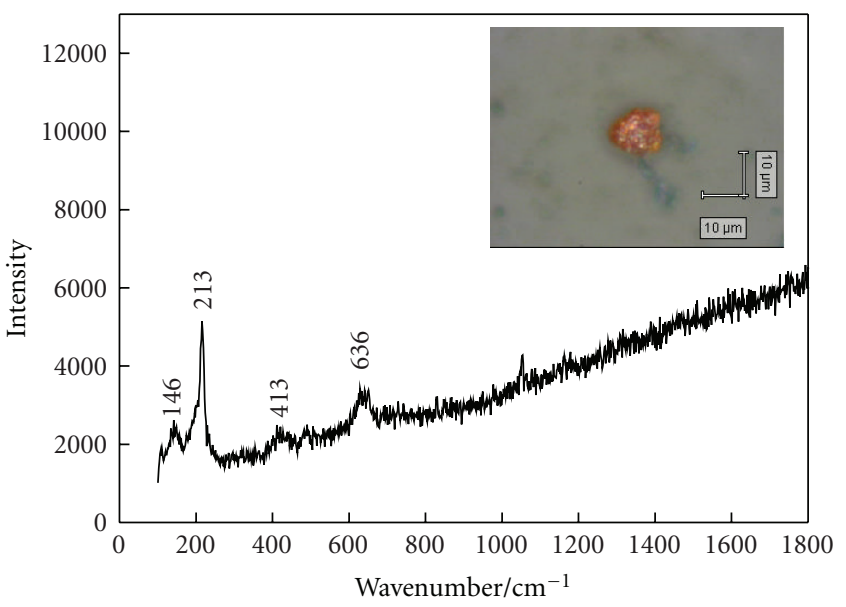

(b)

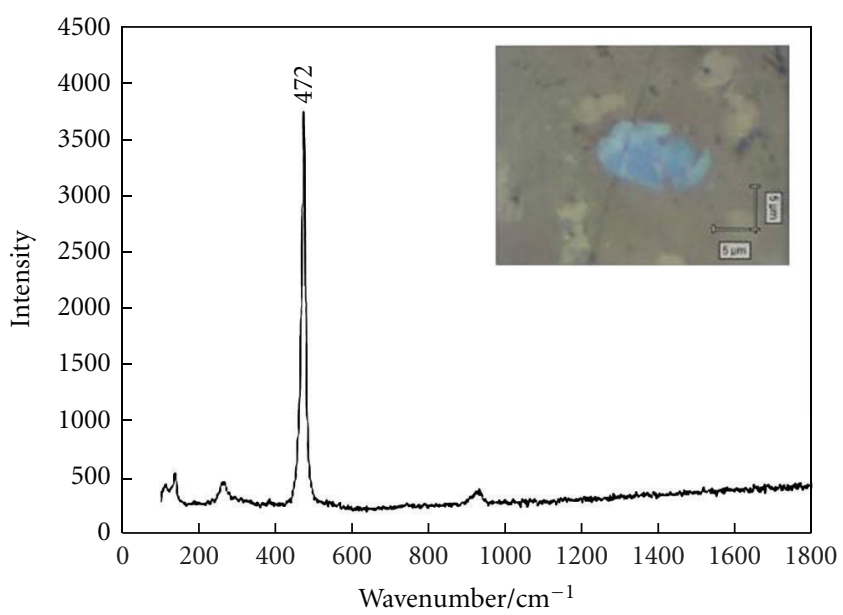

(c)

FIGURE 5: Raman spectrum of corrosion of sample 2: (a) green particle; (b) red particle; (c) blue particle.

Cuprite $\left(\mathrm{Cu}_{2} \mathrm{O}\right)$ is one kind of common corrosive products of bronze wares that underground burial environment $[12,13]$ that would form a tough red layer on the surface of 


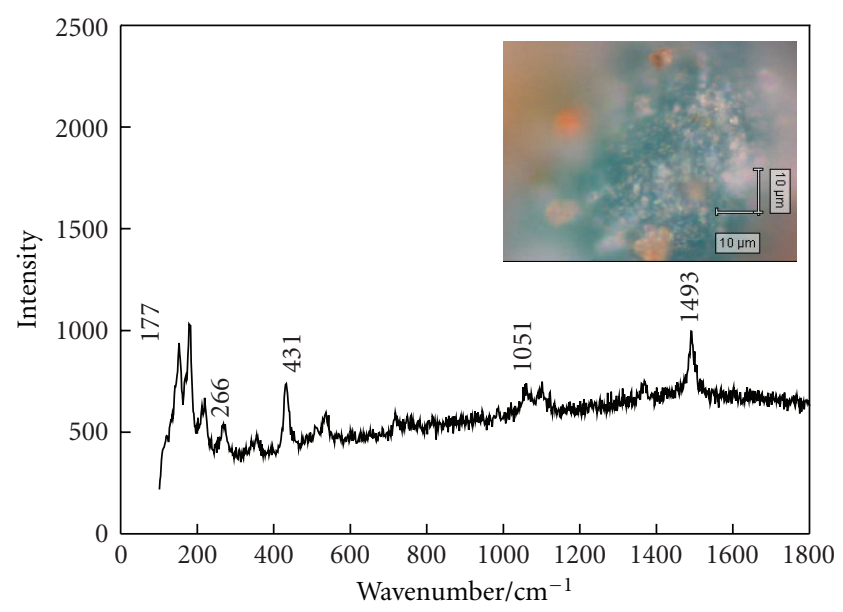

(a)

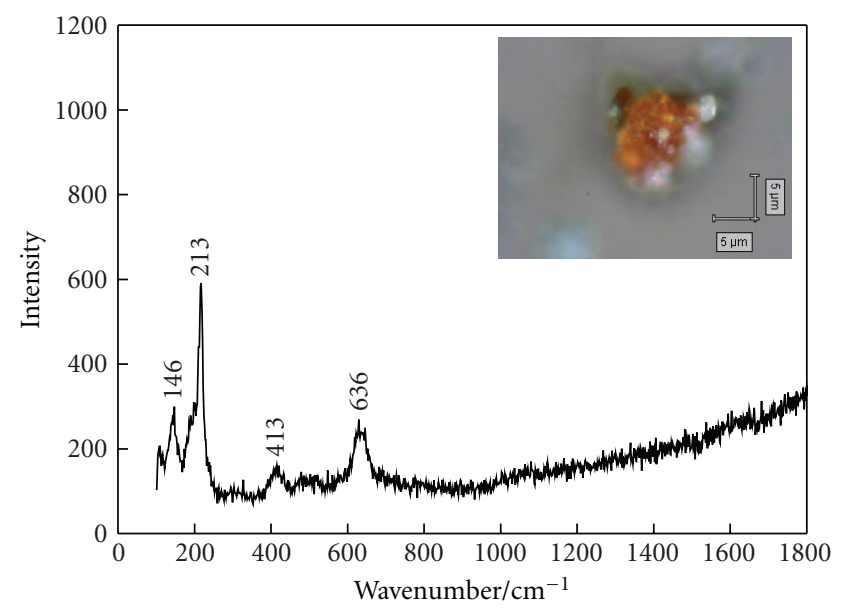

(b)

FIGURE 6: Raman spectrum of corrosion of sample 6: (a) green particle; (b) red particle.

bronze wares, which is regarded to delay corrosion of bronze alloy by keeping the harmful ion out $[6,14]$ and primary electrochemical reaction as follow.

Negative pole:

$$
\mathrm{O}_{2}+2 \mathrm{H}_{2} \mathrm{O}+4 \mathrm{e} \longrightarrow 4 \mathrm{OH}^{-}
$$

Positive pole:

$$
\mathrm{Cu}+\mathrm{H}_{2} \mathrm{O} \longrightarrow \mathrm{Cu}_{2} \mathrm{O}+2 \mathrm{H}^{+}+2 \mathrm{e} .
$$

Actually, transverse cracks observed in $\mathrm{Cu}_{2} \mathrm{O}$ layer of cross section of sample 2 formed a free migrating pathway between the bronze alloy and the burial circumstance. The cracks in $\mathrm{Cu}_{2} \mathrm{O}$ layer are likely to be a lot to produce along with the gradual corrosion of bronzes, its mechanism required further study.

Lead carbonate $\left(\mathrm{PbCO}_{3}\right)$ was confirmed by XRD that was a common lead corrosive phase in bronze wares [15].
Generally, the reaction of $\mathrm{Pb}$ to $\mathrm{PbCO}_{3}$ will occur in burial environment as follow [16]:

$$
\begin{gathered}
\mathrm{Pb}+\mathrm{O}_{2} \longrightarrow 2 \mathrm{PbO}, \\
\mathrm{PbO}+\mathrm{CO}_{2} \longrightarrow \mathrm{PbCO}_{3} .
\end{gathered}
$$

By the result of SEM image and chemical element distribution, the sample 6 showed the migration out of $\mathrm{Pb}$ element form bronze alloy.

\section{Conclusion}

Photograph of cross section and component element data indicates that bronze substrate has been corroded severely, which must be consolidated before its restoration. The SEM image revealed transverse cracks in $\mathrm{Cu}_{2} \mathrm{O}$ layer in sample 2 which had provided the pathway for element diffusion between the bronze alloy and the burial circumstance.

\section{Acknowledgments}

This work has been partially supported by the Sci. \& Tech. Key Projects of Shaanxi Province of China under Grant no. 2009k01-43, by the Fundamental Research Funds for the Central Universities, by social science Fund of Shaanxi Normal University no. 09SYB05, by Scientific Research Project from Education Department of Shaanxi Provincial Government (2010JZ31), and by Cultural Relics Research Project of Chinese State Administration of Cultural Heritage (20090106).

\section{References}

[1] S. Wei-gang, "Xi, Li Yi and Li mountain park-concurrently discuss function of Li Yi of emperor Qin Shihuang mausoleum," Archaeology and Cultural Relics, no. 4, pp. 67-71, 2009.

[2] S. Wei-gang, Study on Qin tombs unearthed from Xin feng, M.S. thesis, Northweat University, 2009.

[3] R. F. Tylecote, "The effect of soil conditions on the longterm corrosion of buried tin-bronzes and copper," Journal of Archaeological Science, vol. 6, no. 4, pp. 345-368, 1979.

[4] L. Yu, Y. Si-xun, and Z. Xiao-mei, "Study on bronze corrosion from Jin State tombs of Zhou dynasty, Tian ma-Qu village," Sciences of Conzervation and Archeaology, vol. 2, pp. 9-18, 2000.

[5] L. Yan-ping, C. Xiao-lin, C. Yu-bin, and W. Zhi-qiang, "Bronze sample corrosion experiment in soil in archaeological site," Archaeology and Cultural Relics, no. 6, pp. 95-98, 2006.

[6] J. Pu-Jun, Q. Ying, H. Ya-Li, H. Si-Ping, and H. Wen-Hu, "Analysis of bronze corrosion product from No.1,2 tombs of Jiu lian dun tombs," Jian Han Archaeology, no. 1, pp. 112-119, 2009.

[7] P. Valério Pedro, R. J. C. Silva, A. M. Monge Soares et al., "Technological continuity in early iron age bronze metallurgy at the South-Western Iberian Peninsula-a sight from Castro dos Ratinhos," Journal of Archaeological Science, vol. 37, no. 8, pp. 1811-1819, 2010.

[8] L. I. McCann, K. Trentelman, T. Possley, and B. Golding, "Corrosion of ancient Chinese bronze money trees studied by 
Raman microscopy," Journal of Raman Spectroscopy, vol. 30, no. 2, pp. 121-132, 1999.

[9] M. C. Bernard and S. Joiret, "Understanding corrosion of ancient metals for the conservation of cultural heritage," Electrochimica Acta, vol. 54, no. 22, pp. 5199-5205, 2009.

[10] S. Xu, Q. Wang, J. H. Cheng, Q. H. Meng, and Y. Jiao, "Preparation and characteristics of porous CuS microspheres consisted of polycrystalline nanoslices," Powder Technology, vol. 199, no. 2, pp. 139-143, 2010.

[11] P. J. Jin, Z. Q. Yao, M. L. Zhang, Y. H. Li, and H. P. Xing, "A pigment $(\mathrm{CuS})$ identified by micro-raman spectroscopy on a chinese funerary lacquer ware of West Han Dynasty," Journal of Raman Spectroscopy, vol. 41, no. 2, pp. 222-225, 2010.

[12] F. J. R. de Oliveira, D. C. B. Lago, L. F. Senna, L. R. M. de Miranda, and E. D'Elia, "Study of patina formation on bronze specimens," Materials Chemistry and Physics, vol. 115, no. 2-3, pp. 761-770, 2009.

[13] W. Hui-Zhen, W. Guo-Feng, Z. Hong, and J. Pu-Jun, "Corrosion mechanism and conservation study of bronze ge of Shang dynasty," Archaeology and Cultural Relics, no. 3, pp. 93-96, 2001.

[14] J. J. Shim and J. G. Kim, "Copper corrosion in potable water distribution systems: influence of copper products on the corrosion behavior," Materials Letters, vol. 58, no. 14, pp. 2002-2006, 2004.

[15] J. La-jiang, "Science and technology archaeology study of bronze of early Qin dynasty," Northwest University, 2010.

[16] E. Rocca, C. Rapin, and F. Mirambet, "Inhibition treatment of the corrosion of lead artefacts in atmospheric conditions and by acetic acid vapour: use of sodium decanoate," Corrosion Science, vol. 46, no. 3, pp. 653-665, 2004. 

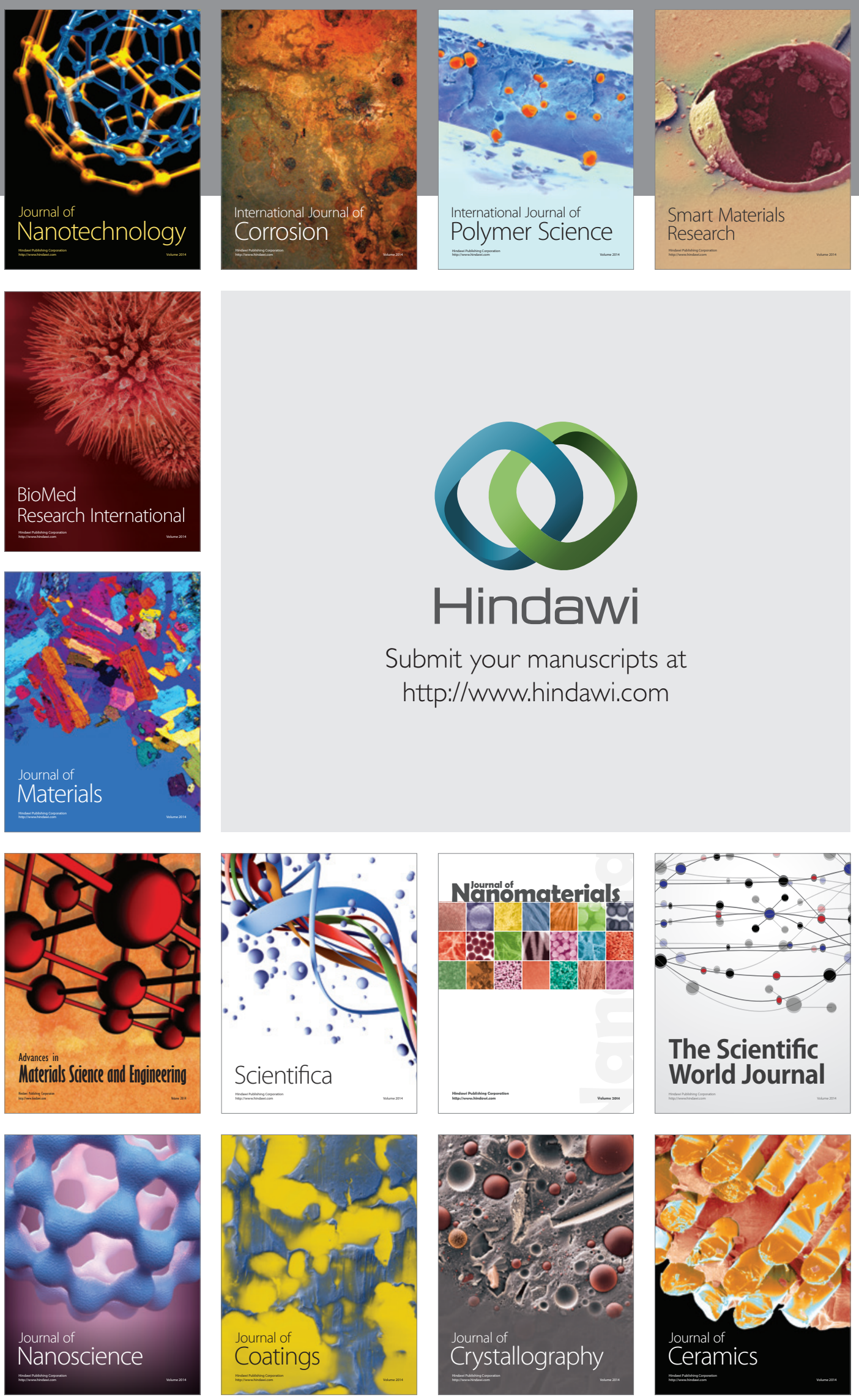

The Scientific World Journal

Submit your manuscripts at

http://www.hindawi.com

\section{World Journal}

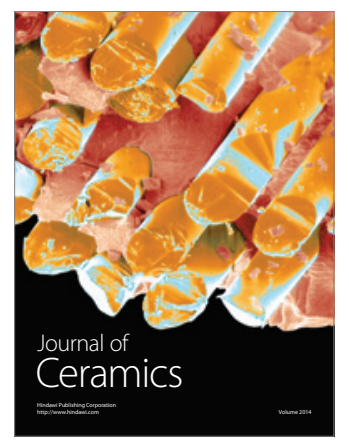

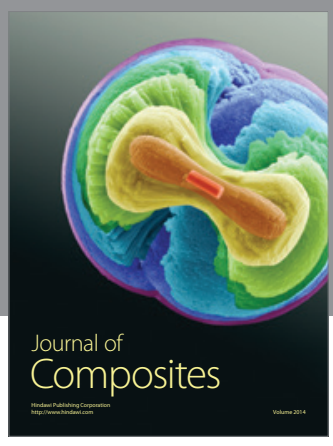
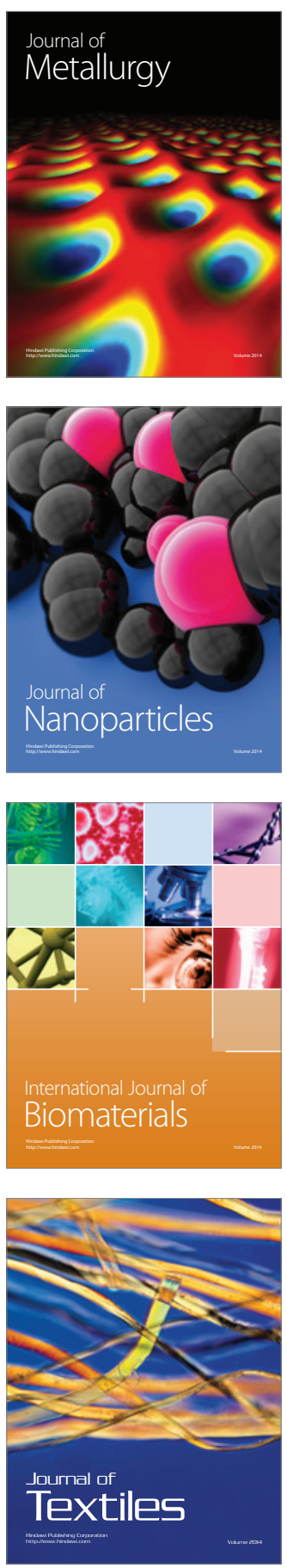